\title{
Measuring the Formaldehyde Content from Different Types of Oriented Strand Board Manufactured with Different Thicknesses and Glued with Different Resins
}

\section{Mjerenje sadržaja formaldehida u pločama s orijentiranim iverjem različite debljine i proizvedenih upotrebom različitih ljepila}

Professional paper • Stručni rad Received-prispjelo: 12. 9. 2016. Accepted-prihvaćeno: 11. 5. 2017. UDK: $630 * 824.328 ; 630 * 863.215$ doi: $10.5552 /$ drind .2017 .1640

\begin{abstract}
This study measures the formaldehyde content (FC) of different types of oriented strand board (OSB) panels. Panels with different thicknesses were produced on the OSB production line of a prominent manufacturer of board composite materials in the Czech Republic. The resins used were polyurethane (PU1, PU2) and melamine-urea-formaldehyde (MUF). The corrected FC from 3-layer OSB/3 panels (MUF/surface, PU2/core) ranged from $5.95 \pm 0.42$ to $7.24 \pm 0.67 \mathrm{mg}$ formaldehyde $100 \mathrm{~g}$ of dry board. The corrected FC of the 3-layer OSB panels bonded with PU2 resin ranged between $0.48 \pm 0.04$ and $0.57 \pm 0.11 \mathrm{mg}$ formaldehyde $100 \mathrm{~g}$ dry board. Additionally, the corrected FC of 3-layer OSB/3 panels bonded with PU1 resin ranged from $0.09 \pm 0.22$ to $0.46 \pm 0.40$ mg formaldehyde/100 g dry board. Furthermore, the corrected FC of 3-layer OSB/4 panels bonded with PU1 resin ranged from $0.178 \pm 0.309$ to $0.473 \pm 0.027 \mathrm{mg}$ formaldehyde $/ 100 \mathrm{~g}$ dry board. These results showed that the FC was limited to the natural content of formaldehyde in solid wood, where the values are extremely low, and which resulted in the production of green product. Additionally, the FC of OSB panels bonded with PU1 was lower than that of panels glued with PU2.
\end{abstract}

Keywords: construction panels, formaldehyde content, green products, OSB

SAŽETAK • U istraživanju je provedeno mjerenje sadržaja formaldehida u različitim tipovima ploča s orijentiranim iverjem (OSB). Ploče različitih debljina izrađene su na proizvodnoj liniji poznatog proizvođača pločastih

\footnotetext{
Authors are visitor researcher and assistant professor at Department of Wood Processing, Faculty of Forestry and Wood Sciences, Czech University of Life Sciences, Prague, Czech Republic. ${ }^{2}$ Authors are associate professor and professor at Forestry and Wood Technology Department, Faculty of Agriculture (EL-Shatby), Alexandria University, Egypt.

Autori su gostujući istraživač i docent Odjela za preradu drva, Fakultet šumarstva i drvne tehnologije, Češko sveučilište prirodnih znanosti, Prag, Republika Češka. ${ }^{2}$ Autori su izvanredni profesor i profesor Odjela šumarstva i drvne tehnologije, Agronomski fakultet (EL-Shatby), Sveučilište u Aleksandriji, Egipat.
} 
kompozitnih materijala u Republici Češkoj. Pritom su upotrijebljene smole poliuretan (PU1, PU2) i melaminurea-formaldehid (MUF). Korigirani sadržaj formaldehida u troslojnim pločama OSB/3 (MUF/površinski slojevi, PU2/srednji sloj) iznosio je od 5,95 \pm 0,42 do 7,24 $\pm 0,67 \mathrm{mg}$ formaldehida u $100 \mathrm{~g}$ suhe ploče. Korigirani sadržaj formaldehida u troslojnim OSB pločama s PU2 smolom kretao se u rasponu između 0,48 $\pm 0,04$ i 0,57 \pm $0,11 \mathrm{mg}$ formaldehida u $100 \mathrm{~g}$ suhe ploče. Dodatno, korigirani sadržaj formaldehida u troslojnim pločama OSB/3 lijepljenim PU1 smolom iznosio je između 0,09 $\pm 0,22$ i 0,46 $\pm 0,40 \mathrm{mg}$ formaldehida u $100 \mathrm{~g}$ suhe ploče. Nadalje, korigirani sadržaj formaldehida u troslojnim pločama OSB/4 lijepljenima PU1 smolom kretao se u rasponu između 0,178 $\pm 0,309$ i 0,473 $\pm 0,027 \mathrm{mg}$ formaldehida u $100 \mathrm{~g}$ suhe ploče. Ti rezultati pokazuju da je sadržaj formaldehida ograničen na prirodni sadržaj formaldehida u masivnom drvu, pri čemu su vrijednosti iznimno niske, što je rezultiralo proizvodnjom zelenog proizvoda. Sadržaj formaldehida u OSB pločama lijepljenima PU1 smolom bio je manji nego u pločama lijepljenima PU2 smolom.

Ključne riječi: građevinske ploče, sadržaj formaldehida, zeleni proizvodi, OSB ploča

\section{INTRODUCTION}

\section{UVOD}

Oriented strand board (OSB) is an engineered wood-based panel consisting of strands of wood that are bonded together with a synthetic resin; the strands are oriented, partially randomly overlapped, and pressed together in layers (Hodoušek et al., 2015). In the outer layers, strands are generally oriented longitudinally in line with the panel length, whereas in the middle layers, strands generally lie perpendicular to the outer layers. Recent methods for manufacturing OSB require very thin, long chips with the following optimum dimensions: 0.4 to $0.6 \mathrm{~mm}$ in thickness, 5 to $20 \mathrm{~mm}$ in width, and 60 to $120 \mathrm{~mm}$ in length )Peña et al., 2006; Ohlmeyer et al., 2008; Böhm et al., 2011).

OSB-like plywood is widely used as a structural material in the manufacture of housing, framing, and other industrial products (Böhm et al., 2012; Salem et al., 2013). Longer and thinner chips that are accurately oriented increase the strength, rigidity, and other physical properties of OSB panels (Han et al., 2006 and 2007).

Additionally, for good production of OSB, the density of the surface layers should be higher than the density of the intermediate layer, with a "U"-shaped density profile along the panel thickness (Xu and Winistorfer, 1995; Painter et al., 2006; Böhm et al., 2011). OSB consists of three layers, and it achieves a high level of dimensional stability with excellent mechanical performance. OSB is manufactured primarily from spruce strands, good quality softwood (Böhm et al., 2011; Hodoušek et al., 2015).

Polyurethane or polyisocyanate resins are widely used in OSB worldwide, MDF mills in Europe, and a few MDF mills in North America (Papadopoulos et al., 2002). It is important to understand how these resins react with wood furnish, as this knowledge will determine whether the urethane linkage will strengthen the board and provide durability in different environmental conditions. Theoretically, isocyanate groups can react with hydroxyl groups in wood furnish and form irreversible urethane linkages (Pizzi and Mittal, 2003; Smith, 2012). Isocyanate-bonded composite panels have benefits including water-resistant chemical bonds, strong mechanical bonds and toughness, high strength, low resin dosage, extreme moisture resistance, and low swelling (Papadopoulos, 1999). Polyurethane can be used in the core layer alone or in all layers of OSB depending on the quality and/or formaldehyde emission restrictions (Vangronsveld et al., 2010).

Formaldehyde emissions (FE) from wood, wood products, and flooring materials are affected by wood type or species, board thickness, resin type, resin additives, panel manufacturing techniques, moisture content, the drying and hot-pressing techniques, and surface finishing materials (Yu and Crump, 1999; Kim et al., 2007; An et al., 2010; Salem et al., 2011; He et al., 2012; Hematabadi et al., 2012; Salem et al., 2012; Kim and Tanabe, 2014). Primarily, the formaldehyde emitted from a new wood-based product comes from free formaldehyde present in the material, and the emission exponentially declines until a steady-state level is reached (Yu and Crump, 1999). Boards bonded with melamine-ureaformaldehyde (MUF) resin exhibit the lowest formaldehyde content (FC) and FE because of the addition of melamine to UF resin (Aydin et al., 2006).

Previously, differences in the bending stress of the upper and lower faces of OSB/3boards and the air permeation rate of $\mathrm{OSB} / 3$ and $\mathrm{OSB} / 4$ boards have been studied (Ohlmeyer et al., 2008; Hodoušek et al., 2015). In the present study, OSB/3 and 4 boards, which are extensively produced in Europe for their use as heavy-duty load-bearing boards in humid conditions, were evaluated to determine their formaldehyde content with the perforator or extraction method (EN 120, 1993).

\section{MATERIALS AND METHODS 2. MATERIJALI I METODE}

\subsection{Production of $O S B / 3$ and $O S B / 4$ panels} 2.1. Proizvodnja ploča OSB/3 i OSB/4

Industrially manufactured $\mathrm{OSB} / 3$ and $\mathrm{OSB} / 4$ panels with various thicknesses were investigated to determine their formaldehyde content during the period of August 2014. All panels were manufactured using $80 \%$ Norway spruce (Picea abies L.) and $20 \%$ Scots pine (Pinus sylvestris L.). According to EN 300 (2006), OSB/3 boards were manufactured as loadbearing boards for use in humid conditions, and OSB/4 boards were manufactured as heavy-duty load-bearing boards for use in humid conditions.

Briefly, mixed wood strands of $80 \%$ Norway spruce and $20 \%$ Scots pine of a predetermined shape with a width of $50 \mathrm{~mm}$, length of $130 \mathrm{~mm}$, and a thick- 
....... Salem, Böhm, Nasser: Measuring the Formaldehyde Content from Different Types...

Table 1 Resin properties of OSB/3 panels

Tablica 1. Obilježja OSB/3 ploča

\begin{tabular}{|c|c|c|}
\hline $\begin{array}{c}\text { Conditions } \\
\text { Uvjeti }\end{array}$ & $\begin{array}{l}\text { OSB/3 Surface layers } \\
\text { OSB/3 površinski slojevi }\end{array}$ & $\begin{array}{c}\text { OSB } / 3 \text { Middle layer } \\
\text { OSB } / 3 \text { srednji sloj }\end{array}$ \\
\hline Raw material / sirovina & \multicolumn{2}{|c|}{ Spruce $80 \%$, Pine $20 \%$ / smrekovina $80 \%$, borovina $20 \%$} \\
\hline Pressing pressure, $\mathrm{N} / \mathrm{mm}^{2}$ / tlak prešanja, $\mathrm{N} / \mathrm{mm}^{2}$ & \multicolumn{2}{|c|}{$<3$} \\
\hline Pressing temperature, ${ }^{\circ} \mathrm{C} /$ temperatura prešanja, ${ }^{\circ} \mathrm{C}$ & 180 to 225 & 180 to 225 \\
\hline $\operatorname{Resin}^{\mathrm{a}} /$ Smola $^{\mathrm{a}}$ & MUF: $35 \mathrm{~kg} / \mathrm{m}^{3},(8.5 \%)^{*}$ & PU2: $12 \mathrm{~kg} / \mathrm{m}^{3},(3.5 \%)^{*}$ \\
\hline Paraffin, $\mathrm{kg} / \mathrm{m}^{3}$ board / parafin, $\mathrm{kg} / \mathrm{m}^{3}$ ploče & \multicolumn{2}{|c|}{2.7} \\
\hline $\mathrm{H}_{2} \mathrm{O}, \mathrm{L} / \mathrm{m}^{3}$ board $/ \mathrm{H}_{2} \mathrm{O}, \mathrm{L} / \mathrm{m}^{3}$ ploče & \multicolumn{2}{|c|}{30} \\
\hline $\mathrm{H}_{2} \mathrm{O}, \%{ }^{\mathrm{b}}$ & 10.5 & 5.5 \\
\hline Hardener, $\%^{\mathrm{c}} /$ očvršśivač, $\%{ }^{\mathrm{c}}$ & \multicolumn{2}{|c|}{2.4} \\
\hline $\begin{array}{l}\text { Wood material, } \mathrm{kg} / 1-\mathrm{m}^{3} \text { of the board, ATRO, coniferous) } \\
\text { drvni materijal, } \mathrm{kg} / 1-\mathrm{m}^{3} \text { ploče, ATRO, četinjače) }\end{array}$ & \multicolumn{2}{|c|}{535} \\
\hline
\end{tabular}

a: Percentage content of component at $0 \%$ moisture / postotni udjel komponente pri sadržaju vode $0 \%$

b: refers to water addition / odnosi se na dodanu vodu

c: refers to catalyst addition (hardener addition) / odnosi se na dodani katalizator (dodani očvršćivač)

ness of less than $2 \mathrm{~mm}$, were used to manufacture OSB panels. The wood strands were dried, mixed, and bonded with $4 \%$ polyurethane type 1 (PU1) and 2 (PU2). The mat was randomly formed and hot-pressed with 5 to $8 \mathrm{~s} / 1 \mathrm{~mm}$ panel thickness at temperatures from 240 to $190{ }^{\circ} \mathrm{C}$ (from entry to output of the press).

Other OSB/3 boards were manufactured using melamine-fortified urea formaldehyde resin (MUF) for the surface layers and PU resin for the core layer with the following categories; OSB/3-A: Surface (MUF) and Core (PU2), OSB/3-B: Surface (PU2) and Core (PU2), and OSB/3-C: Surface (PU1) and Core (PU1). The mat was randomly formed and hot-pressed with 10 $\mathrm{s} / 1 \mathrm{~mm}$ panel thickness at approximately $220^{\circ} \mathrm{C}$. The "ratio of core to surface layers was 60/40. Properties of the resins used are presented in Table 1. Other properties of the resin used for OSB/4 and PU1 have been described previously (Hodoušek et al., 2015).

\subsection{Measuring formaldehyde content by the perforator method (EN 120)}

2.2. Mjerenje sadržaja formaldehida perforatorskom metodom (EN 120)

In Europe and China, the EN 120 perforator method (1993) is the most frequently used procedure for measuring formaldehyde content (FC) as well as for production control in the wood-based panel industry, and it has good correlation with referenced chamber methods (Risholm-Sundman and Wallin, 1999; Salem et al., 2011 and 2012; Liu and Zhu, 2014).

The collected panels were conditioned for 4 weeks at $20{ }^{\circ} \mathrm{C}$ and $65 \% \mathrm{RH}$ before measuring the $\mathrm{FC}$ with the perforator method (EN 120) (Böhm et al., 2012). At least three replicates from each type of OSB were used. Each replicate of approximately $110 \mathrm{~g}$ with dimensions of $25 \times 25 \mathrm{~mm}$ were taken from OSB panels with various thicknesses. The samples were extracted in $600 \mathrm{~mL}$ of boiling toluene for $2 \mathrm{~h}$ in a perforator apparatus. The formaldehyde content was expressed as $\mathrm{mg} \mathrm{HCHO} / 100 \mathrm{~g}$ of dry board (mg/100 g o.d.). The E1 emission limit is $\leq 8 \mathrm{mg} / 100 \mathrm{~g}$ o.d. The measured FC in boards with different moisture content (MC) was normalized to the FC of boards conditioned to $6.5 \% \mathrm{MC}$ according to EN 312 (2003). With MC ranging from 3
$\%$ to $10 \%$, the EN 120 test value was multiplied by a factor $F$, which was calculated from the equation:

$$
F=-0.133 \cdot H+1.86
$$

As formaldehyde content is very sensitive to sample humidity, the moisture content was measured by the following formula (EN 322 1993):

$$
H=\frac{m_{1}-m_{0}}{m_{0}} \cdot 100
$$

where $H$ is the moisture content, $m_{1}$ is the mass of the test pieces before drying $(\mathrm{g})$, and $m_{0}$ is the mass of the test pieces after drying $(\mathrm{g})$.

\subsection{Determination of formaldehyde by the} acetylacetone method

2.3. Određivanje formaldehida acetilacetonskom metodom

The amount of formaldehyde released from panels and absorbed by water was determined photometrically by the acetylacetone spectrophotometric analysis method. This method is based on the Hantzsch reaction, in which aqueous formaldehyde reacts with ammonium ions and acetylacetone to yield diacetyldihydrolutidine (DDL); DDL has an absorption maximum at $412 \mathrm{~nm}$ (Nash, 1953). This technique is widely applied as a standard procedure for the specific analysis of formaldehyde.

\subsection{Statistical analysis \\ 2.4. Statistička analiza}

Measured formaldehyde content was analyzed using SAS version 8.2 (2001). The data were analyzed using analysis of variance in CRD to show the significant differences between the formaldehyde content values with Duncan's multiple-range test at 0.05 level of probability. The values are presented as mean $\pm \mathrm{SD}$.

\section{RESULTS AND DISCUSSION 3. REZULTATI I RASPRAVA}

3.1 Formaldehyde content in different OSB panels 3.1. Sadržaj formaldehida u različitim OSB pločama

The formaldehyde content of OSB panels was extremely dependent on the moisture content of the samples (Tables 2, 3, and 4). It was important that the 
products be near or in equilibrium with the humidity in the test atmosphere (Meyer 1979).

Table 2 shows the measured and corrected FC of 3-layer OSB/3-A panels (MUF/surface, PU2/core). The corrected values ranged between $5.95 \pm 0.42$ and $7.24 \pm 0.67 \mathrm{mg}$ formaldehyde/ $100 \mathrm{~g}$ o.d., and these values are in the range of E1 emission class $(\mathrm{E} 1 \leq 8 \mathrm{mg}$ formaldehyde/100 $\mathrm{g}$ o.d.). The formaldehyde values depended on the oven-dry weight of the board, so that moisture content affected the FC measured by EN 120 (Salem et al., 2012).

Table 3 shows the measured and corrected FC of 3-layer OSB-B bonded with PU2 resin. The lowest value $(0.48 \pm 0.04 \mathrm{mg}$ formaldehyde/100 g o.d.) was found in panels with a thickness of $15 \mathrm{~mm}$, and the highest value $(0.57 \pm 0.11 \mathrm{mg}$ formaldehyde $/ 100 \mathrm{~g}$ o.d. $)$ occurred in panels of 12-mm thickness. The FC of all panels was much lower than required by the E1 emission classification. The variation in minimum and maximum values could be related to the sample taken from the edge of the board or near the center of the board.

Table 4 shows the measured and corrected FC of 3-layer OSB/3-Cpanels bonded with PU1 resin. The corrected FC values ranged from $0.09 \pm 0.22 \mathrm{mg}$ formaldehyde/100 g o.d. (18-mm panels) to $0.46 \pm 0.40 \mathrm{mg}$ formaldehyde/100 g o.d. (20-mm panels). Table 5 pre-

Table 2 Measured and corrected formaldehyde content of 3-layer OSB/3-A panels (MUF/surface, PU2/core)

Tablica 2. Izmjereni i korigirani sadržaj formaldehida u troslojnim pločama OSB/3-A (MUF/površinski slojevi, PU2/srednji sloj)

\begin{tabular}{|c|c|c|c|c|c|c|}
\hline \multirow{2}{*}{$\begin{array}{c}\text { Thickness } \\
\text { Debljina }\end{array}$} & \multicolumn{3}{|c|}{$\begin{array}{c}\text { Measured FC, mg/100 g o.d. } \\
\text { Izmjereni sadržaj formaldehida, mg/100 g o.d. }\end{array}$} & \multicolumn{2}{c|}{$\begin{array}{c}\text { Corrected FC, mg/100 g o.d. } \\
\text { Korigirani sadržaj formaldehida, mg/100 g o.d. }\end{array}$} \\
\cline { 2 - 7 } & $\begin{array}{c}\text { Value* } \\
\text { Srednja } \\
\text { vrijednost }\end{array}$ & $\begin{array}{c}\text { Min. } \\
\text { Minimalna } \\
\text { vrijednost }\end{array}$ & $\begin{array}{c}\text { Max. } \\
\text { Maksimalna } \\
\text { vrijednost }\end{array}$ & $\begin{array}{c}\text { Value } \\
\text { Srednja } \\
\text { vrijednost }\end{array}$ & $\begin{array}{c}\text { Min. } \\
\text { Minimalna } \\
\text { vrijednost }\end{array}$ & $\begin{array}{c}\text { Max. } \\
\text { Maksimalna } \\
\text { vrijednost }\end{array}$ \\
\hline $8 \mathrm{~mm}$ & $5.66 \pm 0.85$ & 3.95 & 6.11 & $7.22 \pm 0.78 \mathrm{a}$ & 5.66 & 7.77 \\
\hline $10 \mathrm{~mm}$ & $5.50 \pm 1.10$ & 3.13 & 6.48 & $7.08 \pm 1.11 \mathrm{ab}$ & 4.63 & 7.89 \\
\hline $12 \mathrm{~mm}$ & $5.97 \pm 0.70$ & 4.49 & 7.19 & $7.24 \pm 0.67 \mathrm{a}$ & 5.65 & 7.96 \\
\hline $15 \mathrm{~mm}$ & $5.16 \pm 0.72$ & 3.68 & 6.38 & $6.48 \pm 0.72 \mathrm{abc}$ & 4.91 & 7.32 \\
\hline $18 \mathrm{~mm}$ & $5.28 \pm 0.49$ & 4.41 & 6.51 & $6.33 \pm 0.57 \mathrm{bc}$ & 5.66 & 7.96 \\
\hline $22 \mathrm{~mm}$ & $4.92 \pm 0.51$ & 4.50 & 5.71 & $5.95 \pm 0.42 \mathrm{c}$ & 5.43 & 6.44 \\
\hline $25 \mathrm{~mm}$ & $5.35 \pm 0.43$ & 4.87 & 5.70 & $6.14 \pm 0.11 \mathrm{c}$ & 6.02 & 6.24 \\
\hline
\end{tabular}

*Mean \pm SD / srednja vrijednost $\pm S D$; Means with the same letter are not significantly different $(P<0.05)$ according to Duncan's multiplerange test. / Prema Duncanovu višestrukom usporednom testu, prosječne vrijednosti označene istim slovom statistički se značajno ne razlikuju $(P<0,05)$.

Table 3 Measured and corrected formaldehyde content of 3-layer OSB-B

Tablica 3. Izmjereni i korigirani sadržaj formaldehida u troslojnim pločama OSB-B

\begin{tabular}{|c|c|c|c|c|c|c|}
\hline \multirow{3}{*}{$\begin{array}{c}\text { Thickness } \\
\text { Debljina }\end{array}$} & \multicolumn{3}{|c|}{$\begin{array}{c}\text { Measured FC, mg/100 g o.d. } \\
\text { Izmjereni sadržaj formaldehida, m/100 g } \text { o.d. }\end{array}$} & \multicolumn{2}{c|}{$\begin{array}{c}\text { Corrected FC, mg/100 g o.d. } \\
\text { Korigirani sadržaj formaldehida, mg/100 g } \text { o.d. }\end{array}$} \\
\cline { 2 - 7 } & $\begin{array}{c}\text { Value* } \\
\text { Srednja } \\
\text { vrijednost }\end{array}$ & $\begin{array}{c}\text { Min. } \\
\text { Minimalna } \\
\text { vrijednost }\end{array}$ & $\begin{array}{c}\text { Max. } \\
\text { Maksimalna } \\
\text { vrijednost }\end{array}$ & $\begin{array}{c}\text { Value } \\
\text { Srednja } \\
\text { vrijednost }\end{array}$ & $\begin{array}{c}\text { Min. } \\
\text { Minimalna } \\
\text { vrijednost }\end{array}$ & $\begin{array}{c}\text { Max. } \\
\text { Maksimalna } \\
\text { vrijednost }\end{array}$ \\
\hline $12 \mathrm{~mm}$ & $0.44 \pm 0.09$ & 0.35 & 0.53 & $0.57 \pm 0.11 \mathrm{a}$ & 0.45 & 0.70 \\
\hline $15 \mathrm{~mm}$ & $0.37 \pm 0.04$ & 0.31 & 0.40 & $0.48 \pm 0.04 \mathrm{a}$ & 0.42 & 0.53 \\
\hline $18 \mathrm{~mm}$ & $0.39 \pm 0.06$ & 0.30 & 0.52 & $0.50 \pm 0.08 \mathrm{a}$ & 0.35 & 0.66 \\
\hline $22 \mathrm{~mm}$ & $0.42 \pm 0.06$ & 0.36 & 0.54 & $0.52 \pm 0.07 \mathrm{a}$ & 0.47 & 0.69 \\
\hline $25 \mathrm{~mm}$ & $0.37 \pm 0.08$ & 0.32 & 0.47 & $0.48 \pm 0.09 \mathrm{a}$ & 0.43 & 0.58 \\
\hline
\end{tabular}

*Mean \pm SD / srednja vrijednost $\pm S D$; Means with the same letter are not significantly different $(P<0.05)$ according to Duncan's multiplerange test. / Prema Duncanovu višestrukom usporednom testu, prosječne vrijednosti označene istim slovom statistički se značajno ne razlikuju $(P<0,05)$

Table 4 Measured and corrected formaldehyde content of 3-layer OSB/3-C panels bonded with PU1 resin

Tablica 4. Izmjereni i korigirani sadržaj formaldehida u troslojnim pločama OSB/3-C lijepljenim smolom PU1

\begin{tabular}{|c|c|c|c|c|c|c|}
\hline \multirow{2}{*}{$\begin{array}{c}\text { Thickness } \\
\text { Debljina }\end{array}$} & \multicolumn{4}{|c|}{$\begin{array}{c}\text { Measured FC, mg/100 g o.d. } \\
\text { Izmjereni sadržaj formaldehida, mg/100 g o.d. }\end{array}$} & \multicolumn{2}{c|}{$\begin{array}{c}\text { Corrected FC, mg/100 g o.d. } \\
\text { Korigirani sadržaj formaldehida, mg/100 g o.d. }\end{array}$} \\
\cline { 2 - 7 } & $\begin{array}{c}\text { Value* } \\
\text { Srednja } \\
\text { vrijednost }\end{array}$ & $\begin{array}{c}\text { Min. } \\
\text { Minimalna } \\
\text { vrijednost }\end{array}$ & $\begin{array}{c}\text { Max. } \\
\text { Maksimalna } \\
\text { vrijednost }\end{array}$ & $\begin{array}{c}\text { Value } \\
\text { Srednja } \\
\text { vrijednost }\end{array}$ & $\begin{array}{c}\text { Min. } \\
\text { Minimalna } \\
\text { vrijednost }\end{array}$ & $\begin{array}{c}\text { Max. } \\
\text { Maksimalna } \\
\text { vrijednost }\end{array}$ \\
\hline $12 \mathrm{~mm}$ & $0.24 \pm 0.26$ & 0.000 & 0.600 & $0.31 \pm 0.34 \mathrm{ab}$ & 0.000 & 0.785 \\
\hline $15 \mathrm{~mm}$ & $0.22 \pm 0.23$ & 0.000 & 0.500 & $0.29 \pm 0.31 \mathrm{ab}$ & 0.000 & 0.678 \\
\hline $18 \mathrm{~mm}$ & $0.07 \pm 0.18$ & 0.000 & 0.600 & $0.09 \pm 0.22 \mathrm{~b}$ & 0.000 & 0.713 \\
\hline $20 \mathrm{~mm}$ & $0.37 \pm 0.32$ & 0.000 & 0.600 & $0.46 \pm 0.40 \mathrm{a}$ & 0.000 & 0.726 \\
\hline $22 \mathrm{~mm}$ & $0.17 \pm 0.24$ & 0.000 & 0.600 & $0.22 \pm 0.30 \mathrm{ab}$ & 0.000 & 0.794 \\
\hline $25 \mathrm{~mm}$ & $0.11 \pm 0.20$ & 0.000 & 0.500 & $0.14 \pm 0.25 \mathrm{~b}$ & 0.000 & 0.624 \\
\hline
\end{tabular}

*Mean \pm SD / srednja vrijednost $\pm S D$; Means with the same letter are not significantly different $(P<0.05)$ according to Duncan's multiplerange test. / Prema Duncanovu višestrukom usporednom testu, prosječne vrijednosti označene istim slovom statistički se značajno ne razlikuju $(P<0,05)$. 
Table 5 Measured and corrected formaldehyde content of 3-layer OSB/4 panels bonded with PU1 resin

Tablica 5. Izmjereni i korigirani sadržaj formaldehida u troslojnim pločama OSB/4 lijepljenim smolom PU1

\begin{tabular}{|c|c|c|c|c|c|c|}
\hline \multirow[t]{2}{*}{$\begin{array}{c}\text { Thickness } \\
\text { Debljina }\end{array}$} & \multicolumn{3}{|c|}{$\begin{array}{c}\text { Measured FC, } \mathbf{m g} / \mathbf{1 0 0} \text { g o.d. } \\
\text { Izmjereni sadržaj formaldehida, mg/100 g o.d. }\end{array}$} & \multicolumn{3}{|c|}{$\begin{array}{c}\text { Corrected FC, } \mathbf{m g} / \mathbf{1 0 0} \mathbf{g} \text { o.d. } \\
\text { Korigirani sadržaj formaldehida, } \mathrm{mg} / 100 \mathrm{~g} \text { o.d. }\end{array}$} \\
\hline & $\begin{array}{c}\text { Value* } \\
\text { Srednja } \\
\text { vrijednost }\end{array}$ & $\begin{array}{c}\text { Min. } \\
\text { Minimalna } \\
\text { vrijednost }\end{array}$ & $\begin{array}{c}\text { Max. } \\
\text { Maksimalna } \\
\text { vrijednost }\end{array}$ & $\begin{array}{c}\text { Value } \\
\text { Srednja } \\
\text { vrijednost }\end{array}$ & $\begin{array}{c}\text { Min. } \\
\text { Minimalna } \\
\text { vrijednost }\end{array}$ & $\begin{array}{c}\text { Max. } \\
\text { Maksimalna } \\
\text { vrijednost }\end{array}$ \\
\hline $15 \mathrm{~mm}$ & $0.240 \pm 0.23$ & 0.000 & 0.500 & $0.295 \pm 0.289 a$ & 0.000 & 0.650 \\
\hline $18 \mathrm{~mm}$ & $0.167 \pm 0.289$ & 0.000 & 0.500 & $0.178 \pm 0.309 a$ & 0.000 & 0.535 \\
\hline $22 \mathrm{~mm}$ & $0.220 \pm 0.205$ & 0.000 & 0.400 & $0.260 \pm 0.239 \mathrm{a}$ & 0.000 & 0.460 \\
\hline $25 \mathrm{~mm}$ & $0.400 \pm 0.000$ & 0.400 & 0.400 & $0.473 \pm 0.027 \mathrm{a}$ & 0.434 & 0.497 \\
\hline
\end{tabular}

*Mean \pm SD / srednja vrijednost $\pm S D$; Means with the same letter are not significantly different $(P<0.05)$ according to Duncan's multiplerange test. / Prema Duncanovu višestrukom usporednom testu, prosječne vrijednosti označene istim slovom statistički se značajno ne razlikuju $(P<0,05)$

sents the measured and corrected FC of 3-layer OSB/4 panels bonded with PU1 resin. The average values ranged from $0.178 \pm 0.309 \mathrm{mg}$ formaldehyde $/ 100 \mathrm{~g}$ o.d. (18-mm panels) to $0.473 \pm 0.027 \mathrm{mg}$ formaldehyde $/ 100$ g o.d. (25-mm panels).

These results showed that FC was limited to the natural content of formaldehyde in solid wood, where the values are extremely low and result in the production of green products. Additionally, the FC values of panels bonded with PU1 were lower than those of panels bonded with PU2. In contrast, the perforator method measures the total extractable formaldehyde in the board, which shows that not all formaldehyde is emitted at room temperature (Xiong and Zhang, 2010).

\section{CONCLUSIONS}

\section{ZAKLJUČAK}

1. The measured formaldehyde content of all OSB panels produced was lower than the E1 emission class.

2. All OSB panels produced with different glues and thicknesses were recognized as green boards.

3. Additional parameters will be studied to measure the physical and mechanical properties of different OSB panels and to provide a better evaluation of the product.

\section{Acknowledgments - Zahvala}

We gratefully acknowledge financial support from the Internal Grant Agency of the Czech University of Life Sciences Prague, Project No. 20174305.

\section{REFERENCES}

5. LITERATURA

1. An, J.-.Y.; Kim, S.; Kim, H.-J., 2011: Formaldehyde and TVOC emission behavior of laminate flooring by structure of laminate flooring and heating condition. J. Hazard. Mater., 187(1-3): 44-51. http://dx.doi.org/10.1016/j.jhazmat.2010.08.086.

2. Aydin, I.; Çolakoğlu, G.; Colak, S.; Demirkir, C., 2006: Effects of moisture content on formaldehyde emission and mechanical properties of plywood. Build. Environ., 41(10): 1311-1316. http://dx.doi.org/10.1016/j.buildenv.2005.05.011.

3. Böhm, M.; Salem, M. Z. M.; Srba, J., 2012: Formaldehyde emission monitoring from a variety of solid wood, plywood, blockboard, and flooring products manufactured for building and furnishing materials. J. Hazard. Mater., 221-222(6): 68-79.

http://dx.doi.org/10.1016/j.jhazmat.2012.04.013.

4. Böhm, M.; Šedivka, P.; Bomba, J.; Reisner, J., 2011: Strength characteristics of OSB in bending - difference between upper and lower panel faces. Drvna industrija, 62(2): 123-127. http://dx.doi.org/10.5552/drind.2011.1036.

5. Han, G.; Wu, Q.; Lu, J. Z., 2006: Selected properties of wood strand and oriented strandboard from small-diameter southern pine. Wood Fiber Sci., 38(4): 621-632.

6. Han, G.; Wu, Q.; Lu, J. Z., 2007: The influence of fines content and panel density on properties of mixed hardwood oriented strandboard. Wood Fiber Sci., 39(1): 2-15.

7. He, Z.; Zhang, Y. P.; Wei, W. J., 2012: Formaldehyde and VOC emissions at different manufacturing stages of wood-based panels. Build. Environ., 47(1): 197-204. http://dx.doi.org/10.1016/j.buildenv.2011.07.023.

8. Hematabadi, H.; Behrooz, R.; Shakibi, A.; Arabi, M., 2012: The reduction of indoor air formaldehyde from wood based composites using urea treatment for building materials. Constr. Build. Mater., 28(1): 743-746. http://dx.doi.org/10.1016/j.conbuildmat.2011.09.018.

9. Hodoušek, M.; Böhm, M.; Lemaster, R. L.; Bureš, M.; Beránková, J.; Cvach, J., 2015: Air permeation rate of oriented strand boards (OSB/3 and OSB/4). BioResources, 10(1): 1137-1148. http://dx.doi.org/10.15376/biores.10.1.1137-1148.

10. Kim, H.; Tanabe, S.-I., 2014: Influence of sorption area ratio and test method on formaldehyde reduction performance for sorptive building materials. Constr. Build. Mater., 70(15): 175-182. http://dx.doi.org/10.1016/j.conbuildmat.2014.07.110.

11. Kim, S.; Kim, J.-A.; An, H.-Y.; Kim, H.-J.; Kim, S. D.; Park, J.-C., 2007: TVOC and formaldehyde emission behaviors from flooring materials bonded with environmental friendly MF/PVAc hybrid resins. Indoor Air, 17(5): 404-415. http://dx.doi.org/10.1111/j.1600-0668.2007.00488.x.

12. Liu, Y.; Zhu, X., 2014: Measurement of formaldehyde and VOCs emissions from wood-based panels with nanomaterial-added melamine-impregnated paper. Constr. Build. Mater., 66(15): 132-137. http://dx.doi.org/10.1016/j.conbuildmat.2014.05.088.

13. Meyer, B., 1979: Urea Formaldehyde Resins, AddisonWesley Publishing, Boston, MA.

14. Nash, T., 1953: The colorimetric estimation of formaldehyde by means of the Hantzsch reaction. Biochem. J., 55(3): 416-421. https://doi.org/10.1042/bj0550416.

15. Ohlmeyer, M.; Makowski, M.; Fried, H.; Hasch, J.; Schöler, M., 2008: Influence of panel thickness on the 
release of volatile organic compounds from OSB made of Pinus sylvestris L. Forest Prod. J., 58(1/2): 65-70.

16. Painter, G.; Husman, H.; Pritzker, M., 2006: Prediction of oriented strand board properties from mat formation and compression operating conditions. Part 1. Horizontal density distribution and vertical density profile. Wood Sci. Technol., 40(2): 139-158. http://dx.doi.org/10.1007/s00226-005-0044-7.

17. Papadopoulos, N. A., 1999: The Effect of Selected Process Variables on the Mechanical Properties and Dimensional Stability of Particleboards, M. S. thesis, University of Wales, Cardiff, UK.

18. Papadopoulos, A. N.; Hill, C. A. S.; Traboulay, E.; Hague, J. R. B., 2002: Isocyanate resins for particleboard: PMDI vs EMDI. Holz Roh Werkst., 60(2): 81-83. http://dx.doi.org/10.1007/s00107-001-0275-8.

19. Peña, S. V.; Rojas, I. M., 2006: Tecnología de la Madera (3rd ed.), Artes Gráficas Cuesta, S.L., Madrid, Spain.

20. Pizzi, A.; Mittal, K. L., 2003: Handbook of Adhesive Technology, Taylor \& Francis Group, New York.

21. Risholm-Sundman, M.; Wallin, N., 1999: Comparison of different laboratory methods for determining the formaldehyde emission from three-layer parquet floors. Holz Roh Werkst., 57(5): 319-324. http://dx.doi.org/10.1007/s001070050351.

22. Salem, M. Z. M.; Böhm, M.; Beránková, J.; Srba, J., 2011: Effect of some manufacturing variables on formaldehyde release from particleboard: Relationship between different test methods. Build. Environ., 46(10): 19461953. http://dx.doi.org/10.1016/j.buildenv.2011.04.004.

23. Salem, M. Z. M.; Böhm, M.; Srba, J.; Beránková, J., 2012: Evaluation of formaldehyde emission from different types of wood-based panels and flooring materials using different standard test methods. Build. Environ., 49(3): 86-96. http://dx.doi.org/10.1016/j.buildenv.2011.09.011.

24. Salem, M. Z. M.; Böhm, M.; Srba, J., 2013: Evaluation of mechanical properties and formaldehyde emission of plywood manufactured for construction applications. Drvna industrija, 64(2): 87-93.

http://dx.doi.org/10.5552/drind.2013.1245.

25. SAS, 2001: User Guide: Statistics (Release 8.02), SAS Institute, Cary, NC.
26. Smith, G., 2012: Lectures and course notes for WOOD 487, Department of Wood Science, University of British Columbia, Vancouver, BC, Canada.

27. Xiong, J. Y.; Zhang, Y. P., 2010: Impact of temperature on the initial emittable concentration of formaldehyde in building materials: experimental observation. Indoor Air, 20(6): 523-529.

http://dx.doi.org/10.1111/j.1600-0668.2010.00675.x.

28. Xu, W.; Winistorfer, P. M., 1995: A procedure to determine thickness swell distribution in wood composite panels. Wood Fiber Sci., 27(2): 119-125.

29. Vangronsveld, E.; Berckmans, S.; Verbinnen, K.; Van Leeuw, C.; Bormans, C., 2010: Isocyanate and total inhalable particulate air measurements in the European wood panel industry. Int. J. Hyg. Envir. Heal., 213(6): 475-488. http://dx.doi.org/10.1016/j.ijheh.2010.08.011.

30. Yu, C. W. F.; Crump, D. R., 1999: Testing for formaldehyde emission from wood-based products - A review. Indoor Built Environ., 8(5): 280-286. http://dx.doi.org/10.1177/1420326x9900800502.

31. *** EN 120, 1993: Wood-based panels -Determination of formaldehyde content -Extraction method called perforator method, European Committee for Standardization, Brussels, Belgium.

32. *** EN 300, 2006: Oriented Strand Boards (OSB) - Definitions, classification, and specifications, European Committee for Standardization, Brussels, Belgium.

33. *** EN 312. (2003). "Particleboard-Specifications," European Committee for Standardization, Brussels, Belgium.

34. ${ }^{* * *}$ EN 322, 1993: Wood-based panels - determination of moisture content, European Committee for Standardization, Brussels, Belgium.

\section{Corresponding address:}

Assoc. Prof. MOHAMED Z. M. SALEM, Ph.D.

Forestry and Wood Technology Department

Faculty of Agriculture (EL-Shatby)

Alexandria University

Alexandria, EGYPT

e-mail: zidan_forest@yahoo.com 